\title{
Investing in publication: researchers as "savage capitalists"
}

\author{
Victor Brun \\ Victor Brun (victor.brun@sciencespo.fr), PSL Université Paris, USR3278 CRIOBE - EPHE-UPVD-CHRS, \\ Perpignan, France
}

\begin{abstract}
The article by Kayal et al. (2021) constitutes an important reminder to the scientific community of some ethical shortcomings of today's academic publishing system for which several solutions are proposed. In this short response, I discuss Latour's portrayal of scientists as "savage capitalists" to relocate a part of these issues in the practices held by researchers themselves. By depicting scientists as capitalist agents publishing articles as investors awaiting returns in capital, I question the compatibility between the stated goal to transform today's publishing system and a potential collective inertia rooted in personal and career goals. So-called "individual solutions" with deep collective and institutional roots are therefore calling for social momentum to effectively be activated; this vision could be translated into more specific goals for future research and actions.
\end{abstract}

Key Words

Academic publishing, Capitalism, Citation, Research ethics, Transformation

\section{Ethical shortcomings of academic publishing}

As they call for a "sustainable academic publishing system", Kayal et al. (2021) criticize fundamental ethical shortcomings in the publication of research findings. In particular, three shortcomings can be noted: a) researchers give away their copyrights and results to publishers for free,

b) the dissemination of knowledge is undermined when it is privately-owned, and,

c) the costs of publishing cause a squandering of public budgets.

At the same time, solutions are proposed and located at the levels of i) individual researchers, ii) scientific communities, and iii) publishers.

In this commentary, I focus on two of these layers: the dispossession of results and copyrights, and individuallevel solutions. I aim to show, first, that understanding the capitalist dynamics internalized by researchers implies seeing publications as investments instead of mere "gifts" to publishers or readers. Second, I discuss how this idea could help refine the so-called "individual solutions"; or in other words, how they should take into account the embeddedness of publication in a larger cycle of scientific credibility.

\section{"Savage capitalists" in action}

In a 1993 book, the anthropologist and philosopher Bruno Latour published an article titled "Portrait d'un biologiste en capitaliste sauvage. [Portrait of a biologist as a savage capitalist $]^{1 "}$ (Latour 2003: 100). Based on an interview, he depicts the ascension in academia of "Pierre Kernowicz" 2 , an apparently renowned French biologist based in the United States. Instead of focusing on the novelty of his ideas and contributions to research, he rather describes his success as a particularly efficient

\footnotetext{
${ }^{1}$ All translations from French are proposed by the author and indicated in italics.

2 The name used is an alias.
} 


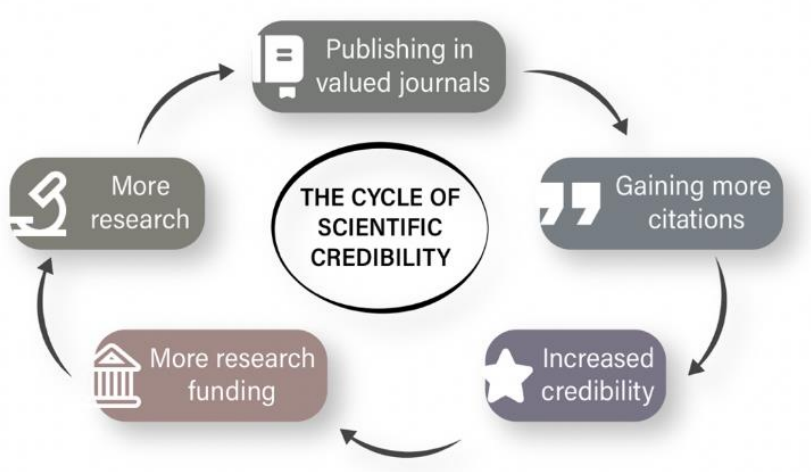

Figure 1. Simplified conceptual diagram representing the cycle of scientific credibility as described in Latour (2003).

accumulation of capital and credibility. Based on Marx, he calls capital "what circulates within a cycle and has no other goal than the expansion of this cycle" (Latour 2003: 107).

"There are topics of research (...), theses, laboratories, concepts, careers (...). [Kernowicz] links them in a cycle from which he computes a global rentability. (...) Testicles heated in bain-marie are changed into figures, transformed into papers which are traded for a PhD, which, with the recognition of a boss, is traded for a position in one of the United States' best laboratories" (Latour 2003: 103-104).

Journal articles and peer reviewing have a "money value" (Copiello 2018) from which funding institutions and researchers are told to be dispossessed - along with their copyrights. They are, according to Kayal et al. (2021: 29), "[given] away (...) for free". Yet, what Latour (2003) describes is a cycle of investment in which research topics and papers are iteratively exchanged for credibility and research funds (Figure 1). Researchers do not give away their discoveries for free, but rather strategically invest in their publication while awaiting later profits responding to their personal and career objectives-more data, more papers, more credibility, etc. Journals with a higher impact factor are known to charge higher publication fees; this fact alone shows the obvious investment component of publishing science. In this "cycle of scientific credibility" (Latour 2003: 107), the differential value associated with journals and alternative modes of publishing science constitutes a critical limit to the solutions based on publishing alone and individual researchers.

\section{Enabling individual-level solutions}

To address the identified ethical shortcomings of academic publishing, Kayal et al. (2021) propose several "individual scientist level solutions". Among them, we can quote auto-publication, and the choice for more responsible journals - the latter sounds similar to consumer-based incentives. However, the doings of researchers are conditioned by what has been termed "academic habitus", or a "feel for the game" with implicit rules allowing ascendancy in a given field (Reay 2004, Bourdieu and Wacquant 1992). One of these constitutive rules is precisely that differential values are associated to different journals and modes of publishing. Individuallevel solutions must therefore be enabled: if we are to change the publishing system, we also have to change the rules of the game.

Expecting for a sudden revision of one's personal and career objectives can prove delusional. Changing the rules, and hoping for a significant number of researchers to publish their articles in alternative journals, or personal blogs for example, could necessitate (at least) two complementary transformations:

- First, the alternative or "more responsible journals" should hold the same value, or a higher one, as compared to traditional journals. This could only be achieved either if the more attractive traditional journals change their publishing processes, or if the attractivity of potentially more responsible journals increases. This option can be seen as a status quo as it does not affect how attractivity and value are conceived, i.e. mainly as a journal's impact factor and associated prestige.

- A second linked transformation should therefore be found in the way publication attractivity is perceived. A successful transformation in the value researchers, funding institutions, and even the public associate with now marginal modes of publishing would allow them to effectively keep translating their research in (capital and) credit while satisfying their personal and career objectives.

That being said, we realize that what appears first as the individual decision to publish in a certain way can only take its roots in collective action. The ubiquitous competition characterizing the academic world (Musselin 2018), and the existence of strong conventions of citation as many common grounds to judge the quality of a scientific piece (Calkins and Rottenburg 2014), shows the difficulties a single well-meaning researcher would face when trying to oppose to them. The battleground for a potential change of publishing standards will therefore be looked for in the collective ability of scientists to make responsible publishing attractive, not only for ethical reasons, but also to keep satisfying the expansion of that investment cycle that we call academic success.

Finally, this whole debate could be taken further to question the very standards of academic success. Not as 
localized, separated and adjustable metrics; but as a globalized capitalist endeavor based on accumulation and diverse forms of dominations against which new types of research could be proposed (Reay 2004, Bishop 1998).

\section{References}

Bishop R. 1998. Freeing ourselves from neo-colonial domination in research: A Maori approach to creating knowledge. Qualitative studies in education 11(2): 199-219. CrossRef

Bourdieu B. and Wacquant L. 1992. An Invitation to reflexive sociology. Chicago: University of Chicago Press.

Calkins S. and Rottenburg R. 2014. Getting Credit for What You Write? Conventions and Techniques of Citation in German Anthropology. Zeitschrift für Ethnologie $139:$ 99-130. CrossRef

Copiello S. 2018. On the money value of peer review. Scientometrics 115: 613-620. CrossRef

Kayal, M., Ballard, J., and E. Kayal. 2021. Transformative choices towards a sustainable academic publishing system. Ideas in Ecology and Evolution 14: 22-30. CrossRef

Latour B. 2003. Portrait d'un biologiste en capitaliste sauvage. In: Petites leçons de sociologie des sciences. Paris: Seuil, pp. 100-12. http://www.brunolatour.fr/sites/default/files/17-K-SAUVAGE-FR.pdf

Musselin C. 2018. New forms of competition in higher education. Socio-economic Review 3(16): 657-683. CrossRef

Reay D. 2004. Cultural capitalists and academic habitus: Classed and gendered labour in UK higher education. Women's Studies International Forum 27: 31-39. $\underline{\text { Crossref }}$ 